\title{
Denunciations and the Uses of Justice
}

On 6 March 1755 Lucia Tessoni, a married spinner of stockings, was treated for a head wound at the Ospedale di Santa Maria della Morte, nearby what is known today as Bologna's Piazza Maggiore. ${ }^{1}$ Notified by the surgeon who treated her 'suspicious wounds,' a notary from Bologna's criminal court visited Lucia at her bedside to ask what had put her in this precarious position. ${ }^{2}$ The situation she described was that of a quarrel that escalated between her and her neighbour Gertrude Carolini. It started out with simple verbal insults, which Lucia decided to denounce to the criminal court. A month later, the two women encountered each other each other again in the loggia of their apartment building and Gertrude started insulting her once more. Lucia warned her that it would be wise to leave her alone; otherwise she would lodge a further complaint against her. As Gertrude replied that she feared nobody, the heated exchange escalated into a fight in which Lucia received blows to her head with a hammer; an attack from which Lucia died later that month.

While Lucia's recourse to the court ended up being in vain for her personally, this example stands as a testament to the agency of ordinary women as litigants - latitude that has had only little attention in earlier scholarship. The previous chapter discussed the offences that came before Bologna's early modern criminal court primarily from the perspective of the prosecution policies of the authorities. Like other early modern criminal courts, however, the Torrone was more than an instrument for the authorities to impose top-down control on its inhabitants. Examining in detail the separately stored denunciations will demonstrate the importance of Bologna's early modern criminal court as a forum for conflict resolution, employed instrumentally and strategically by men and women to pursue their grievances. It will also bring to the fore a richer tableau of women's crimes more representative of their everyday lives than the formal investigations could depict.

This chapter begins with the historiography on women's use of justice in early modern Europe. Together with prescriptive literature, the relatively weak legal position women had in Roman law has provided fuel for notions of a North-South divergence related to the access to and uses of justice. The first section will discuss recent works that call for caution and indicate that the

1 ASBo, Torrone, 8179-2, fasc. 2.

2 Blastenbrei, 'Violence, arms and criminal justice,' 70. 
differences may have been less extreme than such a dichotomy suggests. The next section analyses the denunciations and explains that the types of cases brought before the criminal court diverge significantly from the prosecution pattern because of the court's role as a forum for conflict resolution. While this mechanism has been observed in most early modern European legal systems, it will shed light on some of the ways in which Italy's culture of peacemaking stands out. It then looks at who was able to access and use justice, and stresses the importance of unmediated access to the court for women. Lastly, it examines people's objectives in employing justice, ranging from a real call for intervention by the authorities to a threat and an improvement in the litigant's extrajudicial negotiation power.

Women and the Uses of Justice

Lucia's case against Gertrude is a good example of the way in which ordinary men and women employed the criminal court in their attempts to resolve their everyday conflicts. The notion that judicial institutions should not only be viewed as instruments of top-down control has been conceptualised by Dinges' 'uses of justice.' Drawing on other studies on early modern criminal justice procedures, he argued that the role of the courts in society was equally determined by the people who made instrumental and strategic use of justice as part of a wider set of formal and informal mechanisms. ${ }^{3}$ These men and women did not employ justice solely to obtain a formal conviction from the court, but also - as Lucia's case demonstrates - to try and negotiate other kinds of out-of-court settlements.

It has been suggested that the ways in which people made use of the courts was gendered. Dinges suggests that the judicial records mention fewer women because women were more inclined to solve conflicts through other informal or extrajudicial forms of social control, such as the family or neighbourhood. Women's economically dependent position and legally subordinate status prevented them from making optimal use of generally expensive formal legal procedures. ${ }^{4}$ Furthermore, there may in general have been different gender regimes that created more favourable conditions for women to access and make use of justice. Building on similar (though debated) hypotheses regarding labour force participation, residential arrangements and marriage patterns, the prevailing idea is that in Europe a North-South divide may have

3 Dinges, 'The uses of justice,' 161.

4 Ibidem, 167-168. 
existed in relation to the opportunities that the different juridical and normative systems gave to women and men to perform public roles in society. ${ }^{5} \mathrm{Al}-$ though such a dichotomy has not in itself remained uncontested, Italian women's relatively weak legal position within the patriarchal criminal justice system has contributed to an overall idea of a culture characterised by subordination and constraint, while opportunities for women to participate in public life in northern Europe appear to have been more plentiful. ${ }^{6}$

In the past two decades, it has increasingly been shown how women were able to achieve considerable agency in the management and negotiation of their everyday lives through the instrumental use of law courts. ${ }^{7}$ Much of the research on women's ability to negotiate early modern legal systems has focused on examinations of ecclesiastical courts. Studies on England and Germany have shown that these ecclesiastical courts facilitated the participation of female litigants in a greater number than other courts, and that women employed them to pursue slander and defamation, and above all to strengthen their household authority in marital disputes. ${ }^{8}$

Although ecclesiastical courts have been studied most extensively, they were by no means the only judicial forum employed by early modern women. Various studies have indicated a much larger presence of women as litigants among the lower criminal courts than was previously believed. ${ }^{9}$ For seventeenth- and eighteenth-century London, it has been shown that battered wives and women who fell pregnant after rape were able to gain recompense through the relatively cheap system of recognizances, making use of gendered preconceptions concerning their physical vulnerability. ${ }^{10}$ In seventeenth-century Cheshire these recognizances were also readily employed by women in cases of petty violence, binding over their assailants to peace and good behaviour

For an overview of the development of the notion of a distinct 'Mediterranean model' from the 196os onwards, see Viazzo, 'What's so special about the Mediterranean?,' 111-137. Also see A. Bellavitis and B. Zucca Micheletto, 'Introduction: North versus South - gender, law and economic well-being in the fifteenth to nineteenth centuries,' in A. Bellavitis and B. Zucca Micheletto (eds.), Gender, law and economic well-being in Europe from the fifteenth to the nineteenth century: North versus South? (Abingdon: Routledge, 2019) 1-27.

6 An important scholar criticizing the North-South dichotomy is Zucca Micheletto, 'Reconsidering the southern Europe model,' 354-370; Viazzo, 'What's so special about the Mediterranean?,' 111-137.

$7 \quad$ For a recent historiographical assessment of the legal agency of English women, see Kane and Williamson, 'Introduction,' 1-16.

8 Kane and Williamson, 'Introduction,' 7; L. Gowing, Domestic dangers. Women, words, and sex in early modern London (New York: Oxford University Press, 1996); Schmidt, 'Hausväter vor Gericht,' 213-236.

9 For an overview, see Van der Heijden, 'Women, violence and urban justice,' 71-10o.

10 Hurl-Eamon, Gender and petty violence, 49-64. 
to assert their authority both in and outside the household. ${ }^{11}$ An examination of London's eighteenth-century inexpensive summary courts has furthermore revealed that while assaults between women were often not taken seriously by prosecutors, 'plebeian' women nevertheless regarded these courts as useful public forums for arbitration that they could strategically utilise in the resolution of their violent conflicts with members of their neighbourhood community. ${ }^{12}$

Despite the strong emphasis on the patriarchal orientation of early modern Italian society, a growing body of scholarship increasingly recognises Italian women from all social groups as pragmatic users of the law and the various types of courts in conducting their daily lives. Notably, several important works on ecclesiastical courts in early modern Venice and Rome by Daniela Hacke, Joanne Ferraro and Daniela Lombardi have convincingly argued that while women were undoubtedly victims of patriarchal privilege and an inferior legal status, they did have legal agency and used the court to their advantage in matrimonial disputes. ${ }^{13}$ The majority of matrimonial suits recorded came from women who called on the court to protect their well-being, manipulated neighbourhood opinion in order to forward their cause and drew on a series of tropes like violent marriages and sexual dysfunction to support their claims of separation or annulment.

What legal leeway Italian women had outside marital disputes or extramarital sexuality and before other forums has received less scrutiny. There is a broad conceptual consensus in Italian historiography about early modern justice being utilised rather than merely imposed, but there have been few studies specifically examining the gender dynamics of recourse to the law aside from marital disputes. ${ }^{14}$ There is nevertheless evidence that women's use of other legal forums was not as uncommon as the historiographical silence may suggest. Angelozzi and Casanova's recent work on women's crimes in seventeenthand eighteenth-century Bologna remarked that Italian women displayed a 'remarkable familiarity' with criminal justice. Without expanding the argument further, they asserted that the criminal court records reveal women

11 Ibidem, 65-9o, 130-131; Walker, Crime, gender and social order, 75-112.

12 Gray, 'The regulation of violence in the metropolis,' 79-81.

13 Hacke, Women, sex and marriage; Ferraro, Marriage wars; D. Lombardi, 'Giustizia ecclesiastica e composizione dei conflitti matrimoniali (Firenze, secoli XVI-XVIII),' in S. Seidel Menchi and D. Quaglioni (eds.), I tribunali del matrimonio (secoli XV-XVIII) (Bologna: Mulino, 2001) 577-6o8; L. Ferrante, 'Marriage and women's subjectivity in a patrilineal system,' in M.J. Maynes et al (eds.), Gender, kinship, power. A comparative and interdisciplinary history (New York \& London: Routledge, 1996) 115-130.

Cummins and Kounine, 'Confronting conflict in early modern Europe,' 4. 
demonstrating their "capability of developing effective strategies of accusation and defence." ${ }^{15}$ Elizabeth and Thomas Cohen also mention that the machinery of the law was used by ordinary Romans as an instrument of persuasion or chastisement. A woman's suit for rape, they assert, might have been a plot to either "snag a husband or extort a dowry." ${ }^{16}$ Another study of sixteenth-century prostitutes' recourse to Rome's Governor's Court furthermore provides evidence for the extensiveness of the practice of criminal litigation that may have stretched to even the lowest, marginal reaches of society. ${ }^{17}$ These works suggest that the opportunities women had to use justice in Italy may not have been as different as a simplified North-South model suggests - an inference that merits further investigation.

Both in Italian scholarship and elsewhere, a common critique of the quantitative analysis of criminal trials has been that they measure not the levels of actual criminal behaviour, but rather the functioning of the criminal justice apparatus. ${ }^{18}$ It is argued that the cases that were tried by criminal courts mainly consisted of a selection of the crimes that occurred based on the state's knowledge of offences as well as its interests and prosecutorial priorities. The notion that the trials only represent a small fraction of actual criminal behaviour has been linked to the so-called 'dark number,' a concept referring to those crimes that occurred but were not reported or tried by the state or did not lead to a conviction, which therefore escape historians' awareness. ${ }^{19}$ In this light scholars have argued that examinations of verdicts and sentences only provide a partial view and an underestimation of women's participation in the legal process. ${ }^{20}$ Some have therefore begun examining alternative forms of legal

\footnotetext{
15 Angelozzi and Casanova, Donne criminali, 257.

16 Cohen and Cohen, Words and deeds, 20.

17 E.S. Cohen, 'Honor and gender in the streets of early modern Rome,' Journal of interdisciplinary history 22:4 (1992) 6o9.

18 E. Grendi, 'Premessa,' Quaderni Storici 66:3 (1987) 695-70o; M. Sbriccoli, 'Fonti giudiziarie e fonti giuridische. Riflessioni sulla fase attuale degli studi di storia del crimine e delle giustizia criminale,' Istituzioni giudiziarie, criminalità e storia $29: 2$ (1988) 491-501. This is also reflected upon by for example Van der Heijden, Women and crime, 11; Kilday, Women and violent crime, 2.

19 Van der Heijden, Women and crime, 3.

20 Walker, Crime, gender and social order, 4.
} 
action, such as prosecution by a recognizance, which featured much greater numbers of women in the roles of both complainants and offenders. ${ }^{21}$

In the case of many Italian cities it is possible to gain a broader view of legal action beyond trials by examining the denunciations, i.e. the criminal complaints. Formal statements about alleged crimes were lodged either by state officials or, much more commonly, by aggrieved parties or their kin. In Bologna these denunciations have been preserved in the casebooks of the Torrone's eight notaries, who stored them separately from the trial dossiers. Because these denunciations represent all documented, reported crime, they were understandably much more plentiful than the processi (the investigation dossiers examined in the previous chapter). There were about nine complaints for every initiated formal investigation, amounting to thousands of denunciations each year. ${ }^{22}$ Although these denunciations are by no means an unbiased representation of the entirety of offences that took place in the city of Bologna, they do allow us to gauge reported rather than prosecuted crime. They furthermore present an image that comes closer to the everyday reality of perceived criminality because of the absence of the state's filter of prosecutability as well as the sheer quantity of offences recorded.

The types of offences denounced to the court are shown in table 6. It indicates the distribution of offence categories among 1,358 defendants (903 men, 241 women and 214 offenders whose identity is unknown) for 1,054 criminal complaints sampled between the mid-seventeenth and mid-eighteenth centuries. The largest share of the reported offences was concerned with violence: over two-thirds of the defendants were accused of some kind of physical or verbal aggression. Property crime, mainly consisting of theft, burglary and fencing, but also (much more rarely) of pickpocketing and robbery, was the second most common offence reported to the criminal court. It was among these property crimes that complaints were made against unidentified offenders: over half of the thefts and burglaries from shops and houses were discovered hours after they had occurred and were reported to the court without any knowledge of who had committed the offence. About one-tenth of the denunciations centred on a range of public order for offences, such as the bearing of weapons within the city walls without a licence, not having the correct licence to stay in the city, begging and vagabondage, the violation of banishment and resisting the authorities. Sexual offences, as discussed before, were rarely denounced to the criminal court.

21 Ibidem, 5; Shoemaker, Prosecution and punishment, 207-216; Hurl-Eamon, Gender and petty violence, 129-130.

22

Angelozzi, and Casanova, La giustizia in una città di antico regime, 565, 643 . 
TABLE 6 Reported offences in urban denunciations, ca. 1655-1755

\begin{tabular}{|c|c|c|c|c|c|c|c|c|c|}
\hline \multirow[b]{2}{*}{ Violence } & \multicolumn{2}{|c|}{$\begin{array}{c}\text { Female } \\
\text { defendant }\end{array}$} & \multicolumn{2}{|c|}{ Male defendant } & \multicolumn{2}{|c|}{ Total ${ }^{a}$} & \multicolumn{2}{|c|}{$\begin{array}{c}\text { Unidentified } \\
\text { offender }\end{array}$} & \multirow{2}{*}{$\begin{array}{c}\text { Total in } \\
\text { processi }^{\mathrm{b}}\end{array}$} \\
\hline & 197 & $82 \%$ & 602 & $67 \%$ & 799 & $70 \%$ & 4 & $2 \%$ & \\
\hline Property & 27 & $11 \%$ & 163 & $18 \%$ & 190 & $17 \%$ & 209 & $98 \%$ & $28 \%$ \\
\hline Public order & 11 & $5 \%$ & 119 & $13 \%$ & 130 & $11 \%$ & o & ○\% & $26 \%$ \\
\hline Sex & 2 & $1 \%$ & 5 & $1 \%$ & 7 & $1 \%$ & $\mathrm{O}$ & O\% & $3 \%$ \\
\hline \multirow[t]{2}{*}{ Misc } & 4 & $2 \%$ & 14 & $2 \%$ & 18 & $1 \%$ & 1 & О\% & $1 \%$ \\
\hline & 241 & $100 \%$ & $9 \circ 3$ & $100 \%$ & 1144 & $100 \%$ & 214 & $100 \%$ & $100 \%$ \\
\hline
\end{tabular}

SOURCE: SAMPLE 2 (SEE APPENDIX)

a Total excludes unidentified offenders

b Total from processi is derived from Chapter 3 , table 3

The pattern of crimes denounced resembled that of the investigation dossiers (processi) in broad strokes, but there were also important differences, particularly for female defendants. As we have seen in the previous chapter, violence constituted the largest offence category among the processi, but featured even more prominently among the denunciations. In the processi, about 44 per cent of the male defendants were accused of various violent acts compared to two-thirds in the denunciations. Interestingly, the difference is even larger for women. While a third of the female defendants in the processi were charged with violence, women's violent acts made up 82 per cent of their reported crimes in the denunciations. This observation counters popular assumptions regarding women's passivity in violence and highlights the need for a reappraisal of stereotypical categorizations of 'male' and 'female' crimes. In Bologna the supposedly quintessential 'male crime' of violence bore much greater proportional importance to women's palette of recorded deviancy than that of men. Even though this is not reflected in what magistrates decided to take to trial, the records of women's violent encounters constitute an important point of departure to re-evaluate women's deviant behaviour in general, and what this tells us about their use of justice.

Another aspect that stands out from the denunciations compared to the formal investigations concerns the share of women among offenders. Bolognese women made up 21 per cent of the denounced offenders against a mere five per cent among the processi. The denunciations' higher female crime share was not dissimilar to those found among lower criminal jurisdictions elsewhere in 
early modern Europe. ${ }^{23} \mathrm{~A}$ large share of these female protagonists 'vanished' from the casebooks during the judicial process; a mechanism partially attributable to magistrates' paternalistic attitude towards women's crimes. Yet this did not necessarily mean that these denunciations were futile from the perspective of complainants themselves. To understand why this was the case, we must delve deeper into the functioning of the criminal court and the objectives of litigation.

\section{The Torrone as a Forum for Conflict Resolution}

Discrepancies between crimes denounced and investigated stemmed not only from the magistrates' prosecution priorities, but also from the Torrone's functioning as a forum for conflict resolution. Criminal complaints could reflect the authorities' concerns, as local officials denounced and captured people who acted against public order as described in the city's bylaws. But in the city of Bologna this only constituted a small fraction of the complaints recorded in the criminal casebooks: instead, the large majority of cases were brought within the court's purview by those who were wronged themselves. These aggrieved parties brought to the fore a large number of complaints concerning petty brawls with former friends, acquaintances, neighbours and co-workers; minor crimes among the lower classes that the judges were generally disinclined to prosecute in a full inquisitorial trial. The Torrone's statutes specifically instructed magistrates not to pursue these types of crimes, and judges' manuals discussed alternative instruments appropriate for misdeeds such as these. ${ }^{24}$ In general, these petty offences were treated very much as civil matters rather than criminal concerns, meaning that they were regarded as conflicts between individuals, warranting arbitration and compensation instead of punishment and reform. Interestingly, the Torrone's magistrates accommodated inhabitants' use of the court as a forum for conflict resolution, and are in fact believed to have played an active role in encouraging and pressuring victims and their kin to accept their enemies' peacemaking attempts. ${ }^{25}$

The extent to which inhabitants were able to utilize criminal courts for the purpose of conflict resolution was intimately tied to the historical development of the legal system. Composition and peacemaking had a central

\footnotetext{
23 Van der Heijden, 'Women, violence and urban justice,' 71-10o.

24 Angelozzi and Casanova, La giustizia in una città di antico regime, 391; F. Mirogli, Istruzzioni teorico-prattiche criminali di Filippo Mirogli Romano fiscal generale dedicate alla santita di nostro signore Clemente PP.XIII. Tomo primo (Rome 1758) 80.

Rose, A renaissance of violence, 54 .
} 
function in early modern criminal justice. It aimed to re-integrate the assailant into the fabric of society and was a remnant of the older forms of community justice that customarily occurred extra-judicially. As justice became more hegemonic during the early modern period, communities gradually lost the right to settle disputes themselves. Pardoning by the authorities remained an active component of the justice system throughout the early modern period, as did peacemaking procedures in newly established summary and peacemaker courts at the lower end of the criminal justice system across England and the continent. ${ }^{26}$ Overall, however, it is believed that the increasing institutionalisation and centralisation of judicial administration entailed for communities an overall decline or even disappearance of power to negotiate. ${ }^{27}$

The mixing of law and reconciliation bears particular relevance for the history of crime and criminal justice in Italy. Some scholars have pointed to the intricate relationship between Italy's pervasive culture of peacemaking and the relative social acceptance, legitimacy, and comparatively higher rates of violence. ${ }^{28}$ During the early modern period peacemaking procedures were not repealed but incorporated into the states' developing structures of judicial administration, encouraging arbitration among its plaintiffs and defendants and favouring social harmony over formal judicial intervention. ${ }^{29}$ Although early modern Italian states had an inquisitorial legal system, some accusatory procedures related to peacemaking survived. ${ }^{30}$ Crime victims and their close kin had the right to lodge an accusation against assailants and also had the right to withdraw this complaint following composition. The exact regulations regarding this right to withdraw differed from city to city, and varied over time, but it is clear that plaintiffs before Italian courts had a legitimate and recognised

26 P. King, 'The summary courts and social relations in eighteenth-century England,' Past \& Present 183 (2004) 126-127; Gray, 'The regulation of violence in the metropolis,' 76; G. Vermeesch, 'Reflections on the relative accessibility of law courts in early modern Europe,' Crime, history \& societies 19:2 (2015) 53-76.

27 A. Bettoni, 'Fama, shame punishments and the history of justice in the sixteenth and seventeenth centuries,' in J. Rowbotham, M. Muravyeva and D. Nash (eds.), Shame, blame and culpability. Crime and violence in the modern state (London: Routledge, 2013) 35-36; B. Lenman and G. Parker, 'The state, the community and the criminal law in early modern Europe,' in V.A.C. Gatrell, B. Lenman and G. Parker (eds.), Crime and the law. The social history of crime in Western Europe since 1500 (London: Europa Publications, 1980) 40.

Cummins, 'Forgiving crimes in early modern Naples,' 255; Cummins, and Kounine, 'Confronting conflict in early modern Europe,' 9; Broggio and Caroll, 'Violence and peacemaking in early modern Europe,' 5; Rose, 'Homicide in North Italy,' 20; O. Niccoli, Perdonare, 38-39.

29 Bellabarba, 'Pace pubblica e pace privata,' 189-213.

$30 \quad$ Cummins, 'Forgiving crimes in early modern Naples,' 26o-261. 
basis for negotiation outside of formal judicial intervention. ${ }^{31}$ The Torrone should therefore be seen as a prosecutorial body, a place for summary justice procedures, and as a forum for peacemaking.

The development of an accessible criminal justice system promoting conflict resolution in Bologna was furthermore encouraged by some specific local political developments. According to Rose the establishment of the Torrone as a new, professional criminal court with firm representation of papal authority served to undercut the power of the powerful, rebellious local elite by expanding the papal authority's hold on the community. ${ }^{32}$ As a free and relatively efficient and reliable forum for conflict resolution, the Torrone functioned as an alternative to the capricious and now illegal feudal courts. The inhabitants' use of the criminal justice system was thus considered pivotal to the consolidation of state power and, indeed, men and women increasingly flocked to the court to resolve their conflicts.

In Bologna under papal rule, law and the informal practice of dispute resolution mixed throughout all stages of the criminal justice procedure. The denunciation was not always a request for formal state intervention, but could also function as a stepping stone to settle the conflict out of court. Instruments of infrajudicial conflict settlement included the well-known notarised peace contracts and petitions for pardon. ${ }^{33}$ They also encompassed a range of underexamined semi-informal settlement procedures in which the court's magistrates acted as arbiters, or, perhaps even more commonly, where the mere act of lodging a complaint set reconciliation in motion. The denunciations bear witness to manifold strategies in employing the criminal court to settle conflicts, which will be explored in more detail later on in this chapter. Rather than being emblematic of the authorities' prosecution policies, a large proportion of these criminal complaints are indicative of the interests, priorities and strategies of the plaintiffs.

The Urban Context of Women's Litigation

While the Torrone presented itself as an accessible, reliable and free forum for conflict resolution, there were certain impediments to accessing it. In theory, inhabitants from even the most remote hamlets in the territory could bring

$31 \quad$ Niccoli, 'Rinuncia, pace, perdono,' 234; Cohen and Cohen, Words and deeds in Renaissance Rome, 16, 26.

32 Rose, $A$ renaissance of violence, 43 .

33 Cummins, 'Forgiving crimes in early modern Naples,' 255; Cummins and Kounine, 'Confronting conflict in early modern Europe,' 9 . 
conflicts to the court through an elaborate intelligence network of local officials. In practice, however, location mattered. Bologna's legal territory of 4,000 square kilometres was vast and mountainous, and the Torrone was situated in the city centre of Bologna. Most people from the countryside understandably relied heavily on the official go-betweens to reach the criminal court: over 90 per cent of the cases in the countryside were brought by a massaro. In the city of Bologna individuals could also reach out to local officials such as the ministrale, the massaro's urban counterpart, but could furthermore decide to make a complaint to a notary of the court in person. In the city the large majority of denunciations were made by the victims themselves. The share of urban female litigants was also considerably higher: compared to the countryside, urban women were more than twice as likely to make a denunciation.

Risks and opportunities specific to the urban environment engendered higher shares of women among urban litigants. Women's litigation was intimately tied to the share of female criminals before the court, since many of the denunciations against female offenders were made by other women. One aspect of the urban environment observed across early modern Europe was that female crime was more prevalent than in rural areas. John Beattie was among the first to explain the urban-rural disparity in female crime shares for early modern England by arguing that women in cities lived more independent and public lives. ${ }^{34}$ They had a wider range of economic opportunities and more social contacts, but lacked at the same time the support networks and the communal informal control that could keep women out of the criminal justice system. Evidence from criminal courts in various Dutch, French and English towns has also demonstrated that it was precisely the combination of their independence and vulnerability that contributed to the high crime shares in the urban context. ${ }^{35}$ In Bologna women's crime shares were also higher in the city than in the countryside. Angelozzi and Casanova explained this discrepancy by pointing to the freedom of the city, the less extensive social control exerted by the male authority, the neighbourhood and the parish, as well as the greater opportunities for socialisation that led to more occasions for conflict. ${ }^{36}$

34 Beattie, 'The criminality of women,' 8o-116.

35 Schmidt and Van der Heijden, 'Women alone,' 21-38; Van der Heijden, 'Women, violence and urban justice,' 71-100; K. Lambert, Itinéraires féminins de la deviance. Provence 17501850 (Aix-en-Provence: Presses Universitaires de Provence, 2012); D.D. Gray, Crime, prosecution and social relations. The summary courts of the city of London in the late eighteenth century (Basingstoke: Palgrave Macmillan, 20o9); Shoemaker, Prosecution and punishment, 208-209.

36 Angelozzi and Casanova, Donne criminali, 69. 
The Bolognese case furthermore highlights the factor of access to justice. Robert Shoemaker suggested that the high share of female litigants in urban areas was related to the fact that they were less likely to have access to informal mediators such as local landowners or the clergy. ${ }^{37}$ The denunciations from Bolognese countryside villages are suggestive of the role of the massaro in this process. Ordered to relay crimes that occurred within their assigned territory to the Torrone, these local officials likely functioned as mediators and arbiters in local conflicts in Bologna's surrounding villages. While fights between men made it into the massaro's casebooks, records of women's deviant behaviours were far sparser. According to the dominant 'urban freedom and vulnerability'thesis women's crimes may have been less prevalent in rural areas, making it necessary for fewer women to complain to the massaro. Another scenario is that rural women succeeded better than their urban counterparts in resolving their conflicts informally.

A more pessimistic assessment is that rural women simply had fewer opportunities to use judicial instruments. Angelozzi and Casanova have argued that the sheer dependency on the local officials to register and report matters to the criminal court may have particularly restrained women's possibilities in bringing cases within the court's purview. They asserted that women's complaints were more likely to be deemed unworthy of the massaro's time investment necessary to write down complaints and to investigate the offence. ${ }^{38}$ Women's disputes and petty crimes were therefore less likely to be relayed to the Torrone than men's because of their perceived unimportance. While women's disputes may have also been settled to their satisfaction through these informal means, it is important to note that not only women's preferences determined their involvement of the law. Particularly in the countryside, practical restraints could be decisive.

In the urban environment Bolognese women had better opportunities to formally bring their grievances before the criminal court because they did not have to rely on the assessment, judgment and intervention of a third party. It has been noted that women in the city of Bologna were much more likely to lodge a complaint against their husbands, fathers and brothers for subjecting them to violence, abuse and humiliation than in the countryside, where these matters were either dealt with without resorting to justice or were handled informally by the massaro. ${ }^{39}$ The examination of the denunciations demonstrates that the same is true for other types of offences, such as physical or

37 Shoemaker, Prosecution and punishment, 209.

38 Angelozzi and Casanova, Donne criminali, 70, 257.

39 Ibidem, 118. 
verbal injury. Urban women's greater access to justice impacted the kinds of offences recorded in the casebooks. The ability to lodge a complaint brought with it a new set of possibilities to negotiate and manipulate the outcomes of their disputes. The urban environment may not have provided only a more precarious context that may have prompted deviant behaviour, but it also offered women who were the victims of crime better opportunities to resolve conflicts through the criminal justice system.

\section{$5 \quad$ The Users of Justice}

Who were these women and men appearing before the court to pursue their grievances? In recent years, scholars have called attention to the need to be more specific about which sections of early modern communities made use of justice systems. Importantly, in her historiographical survey of works on both civil and criminal courts, Griet Vermeesch argued for a more socially differentiated analysis of the category of 'ordinary people' who were able to draw on formal legal infrastructures to be able to better assess the developments in the accessibility and functioning of early modern law courts. ${ }^{40}$ In a similar vein, Cohen argued that the catch-all term of 'women' needs to be broken up into differentiating aspects that drastically affected the experiences of activities like litigation alongside gender, such as social class and life cycle. ${ }^{41}$ Whether and under which circumstances women could bring their grievances before the court themselves, or through a legal guardian, was also of importance.

It is generally assumed that in Italy 'ordinary people' were able to employ judicial instruments and courts and instruments in the resolution of their conflicts, but to what extent these ordinary people included women is often not clear. The most explicit evidence on this topic comes not from criminal or civil courts, but from studies on notarial arbitration during the Renaissance period. Based on the records of one Florentine notary, Thomas Kuehn put forward that arbitration was a rather open system used by 'all sorts of people. ${ }^{42}$ Both Andrea Zorzi's and Katherine Jansen's works on thirteenth- and fourteenth-century notarial peace contracts in Florence confirm this view, stating (without elaborating) that the protagonists of notarial peace settlements were generally not aristocratic magnates, but ordinary people, ranging from "humble

40 Vermeesch, 'Reflections on the relative accessibility of law courts,' $56,68$.

41 Cohen, 'Evolving the history of women,' 326.

42 Kuehn, 'Law and arbitration,' 36. 
paupers, servants and shoemakers" to wealthier artisans and merchants. ${ }^{43}$ For fourteenth-century Reggio Emilia, Joanna Carraway Vitiello similarly argues that peacemaking was used by people of every social standing, both men and women. ${ }^{44}$ That these conclusions about the broad participatory basis of private arbitration are also relevant for criminal litigation seems plausible, since private concords could and frequently did halt prosecution before formal legal tribunals.

Some other scholars have called the broad participation of ordinary men and women in the legal process into question. Shona Kelly Wray was among the most explicit critics of this notion based on her examination of private notarial arbitration in fourteenth-century Bologna. She too included peace agreements in her study, but placed them among other notarial compromises that primarily involved the transfer of property to conclude that, overall, most of the disputants actually belonged to the rather narrow societal stratum of the landed elite. ${ }^{45}$ She furthermore noted that even the peace acts, which have been described as daily occurrences among all walks of life, were above all a male endeavour: about nine per cent of the disputants were female, but only about one per cent of the offenders. ${ }^{46}$ While she posits a different perspective on the social composition of users of the law, Wray does remark that people were nevertheless probably more familiar with notarial culture than with the courts, which in her estimation remained foreign to especially women, poor and rural residents. ${ }^{47}$

Studies on later periods are more unanimous in their assessment that litigation in Italy was open to men and women from all walks of life. James Shaw's study on civil litigation in sixteenth- and seventeenth-century Venice argues that while women were underrepresented in the civil court, making up six per cent of all plaintiffs and ten per cent of all defendants, civil litigation was common among the lower classes who sought recompense for crimes, resulting in small claims. ${ }^{48}$ Before the ecclesiastical court during the same period, women constituted the largest proportion of litigants. In her work on marital litigation in sixteenth- and seventeenth-century Venice, Joanna Ferraro calculated that

\footnotetext{
43 Jansen, 'Pro bono pacis,' 428; Zorzi, 'Legitimation and legal sanction,' 34.

44 J. Carraway Vitiello, Public justice and criminal trial in late medieval Italy (Leiden, Brill: 2016) 186.

S.K. Wray, 'Instruments of concord. Making peace and settling disputes through a notary in the city and contado of late medieval Bologna,' Journal of social history 42:3 (2009) 735 .

46 Ibidem, 745 .

47 Ibidem, 751.

48 J.E. Shaw, The justices of Venice. Authorities and liberties in the urban economy, 1550-1700 (Oxford: Oxford University Press, 2006) 19, 166.
} 
TABLE 7 Information about marital and occupational status in the denunciations, ca. 1655-1755

\begin{tabular}{|c|c|c|c|c|c|c|c|c|}
\hline \multirow[b]{3}{*}{$\begin{array}{l}\text { Only marital } \\
\text { status }\end{array}$} & \multicolumn{4}{|c|}{ Women } & \multicolumn{4}{|c|}{ Men } \\
\hline & \multicolumn{2}{|c|}{$\begin{array}{c}\text { Defendant } \\
(\mathrm{N}=\mathbf{2 4 1})\end{array}$} & \multicolumn{2}{|c|}{$\begin{array}{l}\text { Plaintiff } \\
(\mathrm{N}=331)\end{array}$} & \multicolumn{2}{|c|}{$\begin{array}{c}\text { Defendant } \\
(\mathrm{N}=9 \circ 3)\end{array}$} & \multicolumn{2}{|c|}{$\begin{array}{l}\text { Plaintiff } \\
(\mathrm{N}=877)\end{array}$} \\
\hline & 76 & $32 \%$ & 168 & $51 \%$ & 37 & $4 \%$ & 32 & $4 \%$ \\
\hline Only occupation & 32 & $13 \%$ & 23 & $7 \%$ & 453 & $50 \%$ & 460 & $52 \%$ \\
\hline Both & 24 & $10 \%$ & 62 & $19 \%$ & $5^{2}$ & $6 \%$ & 16 & $2 \%$ \\
\hline Neither & 109 & $45 \%$ & 78 & $24 \%$ & 361 & $40 \%$ & 369 & $42 \%$ \\
\hline
\end{tabular}

SOURCE: EXTRACTED FROM SAMPLE 2 (SEE APPENDIX)

women made up 75 per cent of petitioners before the ecclesiastical court. ${ }^{49}$ She also mentions that while the petitioners ranged across the social spectrum, patricians were fewer than the people from the 'common orders,' i.e. middle-to-lower classes, such as weavers, bricklayers, textile workers, merchants and fruit vendors. She suggests that this meant that men and women of all classes "in this urban centre thought they had a real chance to change their domestic circumstances." 50

Less is known about the individuals who appeared before early modern Italy's criminal courts as defendants or plaintiffs. While it is assumed that 'ordinary' men and women also employed criminal justice procedures to pursue their grievances, who these commoners were has remained largely unstudied, especially as far as women are concerned. ${ }^{51}$ This is understandable from the perspective of the source material. As others have noted, the characteristics of wealth and status that marked social division during the early modern period were fluid, and the language of social description was imprecise. ${ }^{52}$ In the Bolognese casebooks recordings of these markers of identity were inconsistent and incomplete, especially at the earliest stages of judicial processes, and furthermore reveal a gendered skew in the information provided (table 7 ). Factors such as provenance and age are meaningful and important, but were sparsely

\footnotetext{
49 Ferraro, Marriage wars, 29.

50 Ibidem.

$51 \quad$ Cummins and Kounine, 'Confronting conflict in early modern Europe,' 4; Niccoli, Perdonare; Cohen, 'Honor and gender in the streets of early modern Rome,' 597-625.

$5^{2}$ T. Hitchcock and R. Shoemaker, London lives. Poverty, crime and the making of the modern city, 1690-180o (Cambridge: Cambridge University Press, 2015) 4.
} 
recorded in the denunciations. What will be treated here are the occupational and marital statuses of plaintiffs and defendants.

Occupation or information on estate was far more commonly recorded for men than for women. The Torrone's casebooks provide information for over half of the men and about a quarter of the women involved in criminal disputes during the mid-seventeenth and mid-eighteenth centuries. The notion that common city dwellers engaged in litigation is reflected in the wide range of occupations recorded in the Bolognese criminal court proceedings. While many nocturnal burglars of houses and workshops remained unidentified, most of those that were identified did not belong to the margins of society, regardless of whether they were men or women. For their livelihood, defendants and plaintiffs of both sexes performed a wide range of professions, from servants, labourers, market vendors, and struggling textile workers, to shopkeepers, skilled master artisans and some public officials such as notaries, and even the occasional beggar found their way to the court to lodge a complaint. Most of the complaints concerned conflicts between those of similar social status. That a broad band of ordinary men and women appeared in the Torrone's records not only as defendants but also as plaintiffs was in part due to the lack of financial barriers. Whereas civil litigation and notarial peace accords were costly, denunciations to Bologna's criminal court could be made at little to no cost.

As opposed to information on occupation or estate, marital status is far more often recorded for women than for men in the criminal court documents. Women were often listed as 'daughter of,' 'wife of' or 'widow of,' whereas men were always referred to as 'son of,' meaning that their marital status must be gleaned from secondary evidence in the denunciations. Such information is provided for the large majority (70 per cent) of the female plaintiffs before Bologna's early modern criminal court, and for 42 per cent of the female defendants, but for less than ten per cent of the male accusers and accused. Nicole Castan also observed this discrepancy in her eighteenth-century French sources, and suggested that the scarcity of this information for men was due to the fact that men's social position was determined far less by marital status than women's was. ${ }^{53}$ There was a notable prevalence of married offenders and victims: of the plaintiffs and defendants before the Torrone whose marital statuses have been recorded, the married group was largest, followed by the unmarried (as in never-married) group and only lastly those who were widowed (table 8).

Judicial documents elsewhere in early modern Europe also reveal similar patterns, though scholars question to what extent this means that it was 
TABLE 8 Marital statuses of defendants and plaintiffs in the denunciations, ca. 1655-1755

\begin{tabular}{|c|c|c|c|c|c|c|c|c|}
\hline \multirow[b]{3}{*}{ Unmarried } & \multicolumn{4}{|c|}{ Women } & \multicolumn{4}{|c|}{ Men } \\
\hline & \multicolumn{2}{|c|}{$\begin{array}{c}\text { Defendant } \\
(\mathrm{N}=\mathbf{2 4 1})\end{array}$} & \multicolumn{2}{|c|}{$\begin{array}{l}\text { Plaintiff } \\
(\mathrm{N}=331)\end{array}$} & \multicolumn{2}{|c|}{$\begin{array}{c}\text { Defendant } \\
(\mathrm{N}=903)\end{array}$} & \multicolumn{2}{|c|}{$\begin{array}{l}\text { Plaintiff } \\
(\mathrm{N}=877)\end{array}$} \\
\hline & 14 & $6 \%$ & 36 & $11 \%$ & 17 & $2 \%$ & 5 & $1 \%$ \\
\hline Married & 84 & $35 \%$ & 176 & $53 \%$ & 71 & $8 \%$ & 42 & $5 \%$ \\
\hline Widowed & 2 & $1 \%$ & 18 & $5 \%$ & 1 & ०\% & 1 & ○\% \\
\hline No data & 141 & $59 \%$ & 101 & $31 \%$ & 814 & $90 \%$ & 829 & $94 \%$ \\
\hline
\end{tabular}

SOURCE: EXTRACTED FROM SAMPLE 2 (SEE APPENDIX)

predominantly married women who sought out and encountered the law. For the recognizances in seventeenth- and eighteenth-century Middlesex, Robert Shoemaker argued that only the marital status of married women was recorded systematically. He therefore assumed that the women whose marital status was not described (71 per cent of all women in his samples) were probably predominantly unmarried. ${ }^{54}$ This led him to conclude that urban single women were most likely to enter into disputes and settle their disputes in or through the court. While it is indeed important to consider the implications of this underreporting, I am unconvinced that all plaintiffs and defendants without a recorded marital status in Bologna's criminal court records were unmarried. Another explanation for the large proportion of married women in the casebooks may be found in the Torrone's function as a forum for conflict resolution: before English's courts too, wives constituted significant proportions of plaintiffs and defendants in assault cases. ${ }^{55}$

Married or not, it is important to stress that most of the urban women brought their own complaints to early modern Bologna's criminal court. Only in fewer than five per cent of the cases and almost exclusively for higher-class women did husbands, fathers, sons or employees make a denunciation in their name. While Renaissance Florence women's legal scope of action is thought to have diminished due to the requirement of legal guardians before the court, seventeenth- and eighteenth-century Bolognese women known to make denunciations for their young sons and also sporadically for their husbands. ${ }^{56}$

\footnotetext{
54 Shoemaker, Prosecution and punishment, 209.

55 Walker, Crime, gender and social order, 76; Beattie, 'The criminality of women,' 102, 106107 .

$5^{6}$ Cohn, 'Women in the streets, women in the courts,' 38; Angelozzi and Casanova, Donne criminali, 463 .
} 
While antico regime Italy's women were normatively protected first by their fathers, husbands or legal guardians, it is clear that this did not necessarily shield them from engaging in criminal behaviour, nor did it prevent them from seeking redress through a criminal court. The different ways in which litigation could serve ordinary men and women in settling their everyday conflicts will be discussed in the next sections.

Making a denunciation to the criminal court was a means to various possible ends. What did men and women hope to get from going to the criminal court? The court records speak to the existence of at least three possible objectives that will be explored in the following paragraphs: the initiation of a criminal prosecution, the bolstering of one's negotiation power, and a hybrid form combining negotiation alongside judicial interference. The wish to initiate a formal prosecution was not perceived as the sole function of the criminal court, but early moderners did certainly look to the criminal courts to seek justice in the sense of a legal conviction of their adversaries. In the Torrone's records we can find references to the desired outcome of castigation by the authorities. In 1674, for example, Barbara, wife of Sabatino Barache, made a denunciation against her neighbour Francesca, who had not only insulted her with many injurious words, but had also damaged two pots and flowers in her yard by throwing stones. ${ }^{57}$ In Barbara's eyes this was clearly retaliation for an earlier incident between their daughters. She concluded her complaint by stating that she was making this denunciation so that Francesca would be castigated. ${ }^{58}$

These kinds of requests were quite common among the seventeenth- and eighteenth-century denunciations. As a matter of fact, the objective of having the antagonist reprimanded occurred often and in a largely standardised form. In addition to the broad request for castigation, plaintiffs would ask for fair punishment. In his denunciation, innkeeper Giacomo Borelli, for example, describes wanting Gio Francesco Rossi punished 'according to what the judicial system prescribed' after realising Rossi had attempted to engage a contract killer as a way to avoid having to pay his debts. ${ }^{59}$

$5^{8}$ Ibidem: "gle ne dò la querela, per che siano castigati."

59 Asвo, Torrone, 66o9, fol. 100: "gli ne do querela, et faccio instantia che il medemo Rossi venghi punito conforme vuole la giustitia." 
TABLE 9 Outcomes of denunciations for theft and violence in urban Bologna, ca. 1655-1755

\begin{tabular}{lccccccccccc}
\hline & $\begin{array}{c}\text { Unknown } \\
\text { outcome }\end{array}$ & Withdrawn & Cancelled & $\begin{array}{c}\text { Surety or } \\
\text { precetto } \\
\text { criminale }\end{array}$ & Indicted & Total \\
\hline Theft & 84 & $56 \%$ & 12 & $8 \%$ & 15 & $10 \%$ & 14 & $9 \%$ & 24 & $16 \%$ & 149 \\
Violence $^{\text {a }}$ & 337 & $42 \%$ & 184 & $23 \%$ & 55 & $7 \%$ & 201 & $25 \%$ & 22 & $3 \%$ & 799 \\
\hline
\end{tabular}

SOURCE: EXTRACTED FROM SAMPLE 2 (SEE APPENDIX), COUNTER PER IDENTIFIED OFFENDER

a The category of violence includes homicide, physical violence resulting in lifeendangering wounds, petty physical violence, verbal aggression and the miscellaneous acts of aggression receiving a precetto criminale

The appeal to court intervention is perhaps clearest in the case of theft. In more than half of the complaints concerning thefts and burglaries, the plaintiff came to the court despite expressing having no knowledge about who the culprit was. As we will see in chapter six, the authorities nevertheless took these kinds of crimes very seriously by the authorities and if caught perpetrators could face a harsh sentence. Asking for intervention by the authorities did not only mean that the offender would be punished for stealing, but could moreover entail that the retrieved stolen goods would be returned to the injured party. Compared to violent quarrels, mentions of out-of-court settlements were significantly less common for denunciations of theft (table 9). Less than one in ten of accused thieves saw the cases against them withdrawn (rinuncia), while complaints against violent offenders were renounced following a settlement in nearly a quarter of the cases.

At the same time, chances of a theft denunciation leading to an indictment and formal investigation also seem to have been higher. Although the administration of subsequent judicial steps was patchy at best, at least 16 per cent of the complaints were followed up by a formal investigation. These were much better odds than for many other offences such as physical violence. Chances of a formal investigation of the case and the possibility of retrieving the stolen goods provided a clear incentive for victims to make an appeal for the prosecution of thieves.

Motives beyond formal intervention often played a role too, regardless of what plaintiffs stated as their reasons for bringing their complaint within the criminal court's purview. The case of the aforementioned Barbara against her neighbour Francesca for insult and property damage, for example, unfolded in a way that so many did: it ended up in a withdrawal of the complaint 
presumably following an extrajudicial financial settlement. ${ }^{60}$ In doing so she followed an established pattern, as by far most of the complaints lodged by litigants of both genders did not result in a 'full trial.' When presented to the court's magistrates, peace agreements - official, notarised documents that brought settlement to a dispute between two quarrelling parties - could and frequently did halt criminal investigations. ${ }^{61}$ The simple juridical withdrawal of the complaint (the rinuncia) bore less social weight than a peace agreement, but was nevertheless an established part of the legal process used by men and women of all social strata. Rita Mariani's study of criminal justice in Crevalcore, a village in the Bolognese countryside also subject to the authority of the Torrone, illustrates how roughly a third of all denunciations between 1633 and 1642 were withdrawn by plaintiffs - highlighting once more the fundamental incorporation of negotiation and conflict resolution into the early modern Italian criminal justice system. ${ }^{62}$

Rather than a straightforward request for court prosecution, litigation must also be viewed as part of a negotiation process. ${ }^{63}$ Based on his reading of various European studies on criminal justice, Dinges argued that plaintiffs of both genders were well aware of the threat emanated by a charge, and tried to employ it as a coercive measure in conflict resolution. ${ }^{64}$ The act of the denunciation to the criminal court added a formal dimension to the negotiation that was considered at the very least to be troublesome to the defendant, and potentially also threatening and shameful. Cohen, in her examination of criminal court proceedings concerning house-scorning in sixteenth-century Rome, has suggested that the act of litigation gave the victims a way to bring down shame on their attackers. ${ }^{65}$ That litigation was considered a part of the negotiation process is confirmed in the Bolognese sources. In 1674, Domenica Galli tried convince fellow market vendor, Antonio di Silvestrone, to stop insulting her on a daily basis, by threatening to lodge a criminal complaint against him. ${ }^{66} \mathrm{Un}$ fortunately for her, he seemed rather unconcerned with the prospect, and told her to go for it.

\footnotetext{
6 А $\quad$ ASBo, Torrone, 7028, fol. $20-21$.

61 Nubola, 'Giustizia, perdono, oblio,' 33.

62 R. Mariani, 'Criminalità e controllo sociale nella Crevalcore', 71-73.

63 Cummins and Kounine, 'Confronting conflict in early modern Europe,' 6.

64 Dinges, 'The uses of justice,' 163; C. Lansing, 'Conflicts over gender in civic courts,' in J.M. Bennett and R. Mazo Karrass (eds.), The Oxford handbook for women and gender in medieval Europe (Oxford: Oxford University Press, 2013) 119.

65 Cohen, 'Honor and gender in the streets of early modern Rome,' 624.

66 Asво, Torrone, 7028 , fasc. 26.
} 
Ambivalence was not a standard response to having been accused of an offence in a court of law. Many plaintiffs in fact found themselves harassed by the defendants after making a denunciation, with demands to retract it and clear their name. ${ }^{67}$ In 1705 Andrea Mascagni referred to the complaint made against him three years earlier by his former female employers as a heavy burden, and requested it be retracted. ${ }^{68}$ That this could happen even years after the fact, demonstrates that a criminal complaint was not considered a triviality. Defendants did not necessarily limit themselves to merely inquiring about a possible withdrawal either. In March of 1675 Francesca Pochettini found herself chased down the street by a dagger-wielding man called Donnino, against whom she had lodged a complaint some two months earlier for unspecified 'insolences. ${ }^{69}$ Rather than withdrawing the complaint, she reported her assailant again. Another example comes from the complaint against Pavolino Balini, who insulted, hit and threatened to kill his fellow coachman Rafael di Negrini with a sword in his hand after he had refused to withdraw a complaint from four years earlier. ${ }^{70}$ After several troublesome encounters, Rafael lodged a new complaint, declaring that he feared for his life after Pavolino had come to his house in the middle of the night. Later that day, an agreement was apparently reached and the complaint was withdrawn. These examples illustrate how litigation was not always a clear-cut request of formal intervention by the authorities per se. Instead, the pressure of an official criminal denunciation was used by ordinary men and women in the negotiation of their interests within the community.

The Bolognese casebooks also reveal hybrid objectives between hoping to achieve concrete action from the authorities and the bolstering of the plaintiff's bargaining power. The appeal to specific legal instruments such as the peace injunction is a good example of this objective, calling into play mechanisms of negotiation, empowerment and shaming alongside judicial interference. This is illustrated by the case of Bolognese biscuit seller Ignazia Odorici, who appeared before one of the Torrone's notaries to file a complaint against Francesca Tacchini, a seller of used goods, on 23 December 1755. Francesca had a way of finding Ignazia wherever she went and always insulted and threatened her. While the underlying causes of the dispute remain undisclosed, Ignazia emphasised that this was a long-lasting conflict that she had been unable to settle herself through other measures. After a particularly vexing day when

\footnotetext{
67 ASво, Torrone, 76o6-1, fasc. 278; 76o6-1, fasc. 81 .

68 Asвo, Torrone, 76o6-1, fasc. 27-30.

69 AsBo, Torrone, 7028, fasc. 254-255.

70 Asвo, Torrone, 6653, fasc. 296-297.
} 
Francesca had also insulted and threatened her family, Ignazia made her way to the court describing 'being compelled to send for an injunction.71 The phrasing here is meaningful: Ignazia did not request just any kind of formal intervention; she assumed she could go to court and get a peace injunction. The court records demonstrate that these legal instruments were not solely topdown measures of control, but that men and women were active and knowledgeable litigators steering the case towards a specific outcome enhancing their negotiating position. In some instances, they were successful.

The precetto de non offendendo (literally an 'injunction to not offend') was a peace injunction issued by the criminal court's judge, most often through summary procedure in the phase of the denunciation. In its function it resembled the recognizances issued by London's Justices of the Peace at the Quarter Sessions as well as so-called 'Letters of Lawburrows' in Scotland. ${ }^{72}$ All of these judicial procedures bound people to keep the peace through sureties or conditional fines. The Bolognese peace injunctions forbade defendants to 'violate or harass' the plaintiff and were, like the recognizances, the most popular form of dealing with assault in Bologna during the seventeenth and eighteenth centuries. ${ }^{73}$ An authoritative eighteenth-century judges' manual described the instrument of the precetto criminale as an easy measure suitable for a wide range of frequent but relatively minor offences (leggiere deliquenze). ${ }^{74}$ These could be violations of the public order such as 'being suspicious' or vagabondage, and could be used to release defendants under the condition that they would present themselves again to the court again if deemed necessary by the authorities. In Bologna between the mid-seventeenth and mid-eighteenth century, the most commonly ordered injunction was the precetto de non offendendo, after verbal or physical (yet not life-threatening) fights.

The Bolognese peace injunctions differed from London's recognizances in their form. As the name suggests, the recognizances entailed a sum of money that would not be forfeited in case of good behaviour. Three sureties pledged this monetary amount as a guarantee that the offender would appear in court to answer to a charge and keep the peace. ${ }^{75}$ No such sureties seem to have been necessary for the Italian peace injunctions, as the precetto functioned more

\footnotetext{
$71 \quad$ ASBo, Torrone, 8171-1, fasc. 275: "sono stato costretta spederle un precetto da questa tribunal."

72 Hurl-Eamon, Gender and petty violence, 130; Kilday, Women and violent crime, 94; Shoemaker, Prosecution and punishment, 207.

73 Hurl-Eamon, Gender and petty violence, 129.

74 Mirogli, Istruzzioni teorico-prattiche criminali, 8o.

75 Dinges, 'The uses of justice,' 162-163; Hurl-Eamon, Gender and petty violence, 129.
} 
like a cautionary and conditional monetary punishment. ${ }^{76}$ The penalties for violation of the injunction differed for men and women but were severe for both, ranging from a hefty monetary fine of 25 to 200 scudi (a servant's monthly wage consisted of about half a scudo) to public flogging for women or a sentencing to the galleys for a certain number of years (five, seven or ten years, or a lifetime) for men. ${ }^{77}$ Another specificity was that while the precetto had a standardised form that included the order to not violate or harass each other any longer, the exact configuration of the injunction could be tailored to the situation presented to the court, including clauses regarding specific places, times of day, or specific unsanctioned behaviour, such as drinking in public. ${ }^{78}$ For the criminal justice system it was therefore a practical tool to achieve public order, since it relied less on active surveillance than on the community's willingness to report violations. ${ }^{79}$ The precetti became increasingly used throughout the early modern period: in the Bolognese casebooks the share of the peace injunctions increased from around seven per cent of all recorded outcomes of denunciations in 1650 to around 16 per cent in the mid-eighteenth century.

The state and the urban authorities were not the only actors who had a stake in the injunctions; plaintiffs did too. Like London's recognizances and Scotland's Letters of Lawburrows, the seventeenth- and eighteenth-century Bolognese peace orders were especially popular among women. ${ }^{80} \mathrm{By}$ the end of the seventeenth century the precetto had a distinctly urban character and seemed to have been of particular importance to female plaintiffs and defendants: 27 per cent of all denunciations brought before the Torrone by a female plaintiff resulted in a precetto against their adversary, compared to only 12 per cent of denunciations by male plaintiffs. Out of the 196 peace injunctions issued for violence in my samples, women were relatively over-represented both as plaintiffs ( 42 per cent of all plaintiffs) and as defendants ( 42 per cent of all defendants) compared to their proportionally lower share among violent offenders. ${ }^{81}$

${ }_{76} \quad$ There are references to the surety of the precetto de non offendendo in Rome: Fosi, Papal justice, 64 as well as in Bologna: Angelozzi and Casanova, La nobiltà disciplinata, 164-189.

77 M. Di Sivo, 'Per via giustizia. Sul processo penale a Roma tra XVI e XIX secolo,' Rivista storica del Lazio. Giustizia e criminalità nello stato pontificio 9: 4 (2001) 30.

78 M.A. Savelli, Pratica universale del dottor Marc Antonio Savelli (Parma 1717) 227.

79 S. Hughes, Crime, disorder and the Risorgimento. The politics of policing in Bologna (Cambridge: Cambridge University Press, 2002) 72, 79, 89.

$80 \quad$ Hurl-Eamon, Gender and petty violence, 130; Shoemaker, Prosecution and punishment, 207; Kilday, Women and violent crime, 94 .

81 In the 684 cases concerning all kinds of violence collected for this sample of denunciations, with 919 defendants, women made up $22.3 \%$ of the defendants and $30.2 \%$ of the plaintiffs. 
Theoretically there was no legislative distinction between the city and the countryside, but the court proceedings clearly show that precetti were mainly issued to city dwellers who had made a denunciation in person. ${ }^{82}$ As mentioned before, urban women were not only more likely to become involved in criminal activities compared to their rural counterparts, but also had better access to the criminal justice system to make a denunciation. Without having to rely on local officials as go-betweens, plaintiffs were apparently better able to present their grievances in such a way that they could call upon this legal instrument.

Why were women disproportionally represented among plaintiffs and recipients of peace injunctions? On the one hand, the criminal court may have been more inclined to issue a restraining order for female plaintiffs due to women's perceived weakness and their need for protection. The prevailing chivalry theory assumes that early modern as well as modern legal professionals were generally inclined to protect 'weak women' by treating them with leniency in sentencing. ${ }^{83}$ It seems plausible that this motive of protection played a similar role in the disproportional adjudication of the peace injunctions to female plaintiffs and defendants. Even if the woman was the aggressor against a male plaintiff, the idea that women needed to be protected 'against themselves' may be viewed from this perspective. This protection motive is reinforced by the fact that Italy's ecclesiastical courts ordered comparable peace orders to husbands who mistreated their wives. ${ }^{84}$ According to the canonical treaties, women had the right to ask for a so-called cauzione di non offendere, a similar kind of security deposit intended to ensure that she would not be violated again.

Women themselves may have also preferred appealing to these particular means over seeking more informal community mediation methods or violent confrontation. While the court records certainly attest to women's ability and audacity in violently confronting their male and female adversaries, women, unlike men, had little honour to gain from it as it was considered 'unladylike' comportment frowned upon by contemporaries. ${ }^{85}$ Historians of the nineteenth century have also argued that while women employed violence, it did not have specific resonances for their identity as women. ${ }^{86}$ Because the

\footnotetext{
$82 \quad$ My sample counts only 2 countryside precetti (o.6\% of the cases).

83 Graziosi, 'Women and criminal law,' 166-181; Angelozzi and Casanova, Donne criminali, 227-254.

84 Cavina, Nozze di sangue, 119.

85 Ibidem, 616; Brackett, Criminal justice and crime, 133-134.

86 S. D'Cruze, 'Unguarded passions. Violence, history and the everyday,' in S. D'Cruze (ed.), Everyday violence in Britain, 1850-1950. Gender and class (Harlow: Longman, 2000) 14.
} 
practice of asking the authorities for a forced peace had no place within the traditional masculine conventions of honour, men may have more readily opted for other responses, such as peacemaking or even the challenge to a fight, as these entailed higher esteem than court-ordered sanctions. ${ }^{87}$

In the process of conflict resolution, coercive instruments like the precetto may have afforded more bargaining power particularly to those who customarily lacked it. Cohen has expressed a similar view in her examination of prostitutes' recourse to the criminal court in sixteenth-century Rome. While she argued that established households might resolve attacks on honour via other routes, prostitutes found in the criminal tribunal a "public and socially sanctioned forum in which to air their grievances and, within the conventions of honour culture, to spread shame on their attackers." ${ }^{88}$ Nicoletta Rolla argued along a similar vein for eighteenth-century Turin. ${ }^{89}$ Litigation may have been a means for women to find an alternative response to violence. It not only spared them the inconvenience and potential further dishonour of other possible strategies, but also augmented their leverage. For London, it has been argued that the motive behind assault prosecution was to achieve some kind of compensation for the injuries that were inflicted, either financial or in the form of public apologies for attacks on their characters as well as their bodies. ${ }^{90}$ What the litigious Bolognese women expected of the law was not just an effective protection from their assailants, but also encompassed the negotiation of authority and power, with offenders whom they would not challenge to a fight.

Conclusion: Criminal Litigation, Gender and Agency

Overall, the dominance of the notion of women's inferior legal status derived from Roman law has contributed to the idea that women may have had limited legal agency, yet the examination of the Bolognese criminal court in the seventeenth and eighteenth centuries provides further evidence for a more diverse practice in which women, like men, employed justice strategically to settle their conflicts. Not only does this confirm the notion proposed in other studies that women had certain legal agency within the household, it also shows that this extended to areas outside the home. Various works have already shown

\footnotetext{
$87 \quad$ Dinges, 'The uses of justice,' 163 .

88 Cohen, 'Honor and gender in the streets of early modern Rome,' 624.

89 N. Rolla, 'Per strada e in giustizia. Strategie di difesa dentro e fuori il tribunale (Torino, XVIII secolo),' Quaderni storici 141:3 (2012) 654-656.

90 Gray, 'The regulation of violence in the metropolis,' 81,83 .
} 
that women did not have to submit to mistreatment and could (and did) seek redress in ecclesiastical tribunals. ${ }^{91}$ The criminal court records shed further light on this relationship between women and their communities. In this formal legal structure of the criminal court, women found a forum through which they could wield and manipulate the power of social control and exert it over their community members.

While the authorities' disinterest in prosecuting petty offences seems nondiscriminatory, the experiences of litigation were undeniably gendered. In the Bolognese case, the reliance on male local officials in the countryside to relay cases to criminal court established a very structural impediment to women's formal access to justice. It has been argued that for women more so than for men, direct access to the court was pivotal since the local officials were representatives of a culture that was biased against them. Women's use of criminal justice was therefore largely an urban preserve. The Torrone's function as a forum for conflict resolution opened up the chances for men and women to use the court to pursue relatively petty grievances within their community, especially in cases of non-lethal violence. Whether urban women were more violent, more subjected to formal control or simply more litigious remains an open question, but what is certain is that the urban context did provide better opportunities for women to seek redress before the criminal court.

Compared to men, women could more often (in relative terms) count on the legal instrument of the peace injunction for violent offences. It does not seem unlikely that the importance of this conditional punishment for women was related to a protective motive from the judicial apparatus, but to understand its function it is also crucial to emphasise that women consciously used it as part of their negotiations. The ability to negotiate legal jurisdictions depended on various factors such as socioeconomic status, as well as the expectations of the law. ${ }^{92}$ The criminal court records provide evidence that women were wellaware of the existence and threatening function of the peace injunctions, and expected to have a good chance of obtaining them. The very concrete inconvenience of conditional high fines, supplemented with corporal punishment and forced labour (in the case of male defendants) or public whipping (for women), provided useful leverage in the resolution of everyday conflicts. That Italian women made these requests in the face of a patriarchal legal system suggests that they in practice had more legal agency than their legal position alone would allow us to assume. An unintentional outcome of the patriarchal system was that women's supposed marginality meant not that they were

$91 \quad$ Hacke, Women, sex and marriage; Ferraro, Marriage wars.

92 Kane and Williamson, 'Introduction,' 3. 
powerless, but that they were in some cases able to turn their status into bargaining power instead. ${ }^{93}$

93 A similar conclusion is drawn from rural weaver women's petitions to counter guild claims, see Dumont, 'Women and guilds,' 5-25. 